\title{
STUDYING SOME OF THE MECHANICAL AND PHYSICAL PROPERTIES OF COLORED GEOPOLYMER CONCRETE
}

${ }^{\star}$ Mohammed H. Mahmud ${ }^{1}$

\section{Mohammed A. Abdulrehman ${ }^{1}$}

\begin{abstract}
This study has been done to study the physical and mechanical characteristics of colored geopolymer concrete by adding two types of pigments yellow (iron oxide hydroxide) and blue (cobalt) with three additional proportions for each of the listed colors $(0,2,4,6 \% \mathrm{wt})$, some materials which are available in the native market and other materials imported from outside of the country. The experimental investigation has dealt with the fresh properties(slump) of the colored geopolymer concrete mixes as well as some of the mechanical and physical characteristics of the hardened concrete by testing specimens in compressive strength, flexural strength, water absorption, Rebound number (RN), and ultrasonic pulse velocity (UPV). In addition to that, Finding a relationship between the destructive (strength of compressive) and (RN and UPV) tests. Show us that ( $2 \%$ wt) pigment percentage gives the best results.
\end{abstract}

Keywords: Geopolymer, Colored, Concrete, Compressive strength, UPV, Flexural strength

\section{Introduction}

Geopolymer concrete is a relatively considered new environmentally friend binder material for partial or total replacement of conventional ordinary Portland cement in concrete which produces a high rate of carbon dioxide. Joseph Davidovits (1978) developed an alkaline liquid that can react aluminum $(\mathrm{Al})$ and silicon $(\mathrm{Si})$ in materials of secondary product such as fly ash, metal slag, or metakaolin (MK).
Davidovits coined the term geopolymer to describe this new binder material due to polymerization that occurs in that situation [1]. The first colored concrete was created in the early 1950 s by the F.D. Contractors in Southern California were introduced to the concept of introducing synthetic iron oxide, which was then a waste product from chemical processing to their gray concrete mix by the Davis group [2]. Many researchers have studied geopolymer concrete and colored concrete such as MarínLópeza had made a comparison between the characteristics of Portland cement concrete as well as metakaolin-based geopolymer concrete [3], Rovnaník has investigated the influence on the strength of compressive and flexural strength of different curing temperatures and times of metakaolin-based geopolymer [4], Cheng et al. had used Geopolymer to study the adsorption of heavy metals. The geopolymer was created by condensing a fixed ratio of $\mathrm{MK}$ and alkali solution at a temperature of room and precrushing to a constant radius scale [5], Al-Shathr et al. has investigated the influence of various treatment systems on the strength of Metakaolinbased Geopolymer [6], Sahar et al. had looked into the structural behavior of reinforcement Geopolymer concrete wall [7], Bruce and Rowe

*Corresponding Author: ebma004@uomustansiriyah.edu.iq 
had investigated the basic characteristics of (9) pigments commonly used in concrete block paving [8], Hyun-soo et al. had al. had looked into iron oxide pigments' effects on the characteristics of interlocking blocks of concrete [9], Fujii, et al. had looked into the dosage and form of pigment affect the color of concrete [10], Hospodarova et al. had studied some of the physical and mechanical characteristics of the pigment compounds (liquid case) in the first alternative, with the study of pigment in the liquid case with fly ash (the second alternative) [11]. In this study, we will consider the addition of some pigments to geopolymer concrete and study some of the physical and mechanical properties.

\section{Important of the work}

Since geopolymer produces carbon dioxide less $80 \%$ of ordinary cement, according to previous researches [12]. Through this research, we were concluded that it is possible to use geopolymer as an alternative to concrete when applying colored concrete.

\section{Materials and Experimental work}

\subsection{Materials}

Colored geopolymer concrete materials include (metakaolin, fine aggregate, coarse aggregate, alkaline solution $\left(\mathrm{Na}_{2} \mathrm{SiO}_{3}+\mathrm{NaOH}\right), \mathrm{HRWR}$, Additional water, and pigments.

\subsubsection{Metakaolin(MK)}

Kaolinite's chemical structure is $\mathrm{Al}_{2} \mathrm{Si}_{2} \mathrm{O}_{5}(\mathrm{OH})_{4}$; MK is a dehydroxylated mineral clay kaolinite type linked to the reaction [13]

$$
\mathrm{Al}_{2} \mathrm{Si}_{2} \mathrm{O}_{5}(\mathrm{OH})_{4} \rightarrow \mathrm{Al}_{2} \mathrm{Si}_{2} \mathrm{O}_{7}+2 \mathrm{H}_{2} \mathrm{O}
$$

The synthetic investigation, Metakaolin's real characteristics, and the necessities of Chemical of Pozzolan ASTM C 618 [14] are represented in Tables (1), (2), and(3).
Table 1. Metakaolin chemistry analysis*

\begin{tabular}{cc}
\hline oxides & Content, percent \% \\
\hline $\mathrm{K}_{2} \mathrm{O}$ & 0.27 \\
$\mathrm{Na} 2 \mathrm{O}$ & 0.22 \\
$\mathrm{MgO}$ & 0.15 \\
$\mathrm{~L} . \mathrm{O} . \mathrm{I}$ & 0.71 \\
$\mathrm{TIO}_{2}$ & 0.8 \\
$\mathrm{Fe}_{2} \mathrm{O}_{3}$ & 0.92 \\
$\mathrm{CaO}$ & 1.37 \\
$\mathrm{SO}_{3}$ & 0.45 \\
$\mathrm{Al}_{2} \mathrm{O}_{3}$ & 39.00 \\
$\mathrm{SiO}_{2}$ & 54.2 \\
\hline
\end{tabular}

* done by Geological Survey of Iraq, department of central laboratories

Table 2. Metakaolin physical characteristics

\begin{tabular}{rr}
\hline Physics properties & Result \\
\hline Color & Off-white \\
Physical & Powder \\
Specific gravity & 2.64 \\
Surface area, $\mathrm{m} 2 / \mathrm{g}$ & 13.3 \\
\hline
\end{tabular}

Table 3. Natural Pozzolan Chemical Requirements under ASTM C618

\begin{tabular}{|c|c|c|}
\hline $\begin{array}{l}\text { Composition of } \\
\text { Oxide }\end{array}$ & $\begin{array}{l}\text { Pozzolan } \\
\text { (Class N) }\end{array}$ & MK \\
\hline $\begin{array}{c}\text { Loss on ignition, (max } \\
\%)\end{array}$ & 10 & 0.71 \\
\hline $\mathrm{SO}_{3},(\max \%)$ & 4 & 0.45 \\
\hline $\begin{array}{c}\mathrm{SiO}_{2}+\mathrm{Al}_{2} \mathrm{O}_{3}+\mathrm{Fe}_{2} \mathrm{O}_{3} \\
(\min \%)\end{array}$ & 70 & 94.12 \\
\hline
\end{tabular}

Metakaolin was passed through a sieve (75) $\mu \mathrm{m}$ and retained in sieve (45) $\mu \mathrm{m}$. 


\subsubsection{Sodium Hydroxide}

$\mathrm{NaOH}$ is commercially available 98 percent pure sodium hydroxide in flake shape solids should be dissolved in water purified to provide the quantity required in a solution. The solution of geopolymer concrete is made using sodium hydroxide. To prepare sodium hydroxide used dissolution of flakes of caustic soda in water may help. Cooling of the solution is advised by exposure to air for a while (two hours at least). The descriptions of the $\mathrm{NaOH}$ solution used in the analysis by ASTM E 291 can be found in the table (4) [15].

Table 4. Characteristics Sodium Hydroxide*

\begin{tabular}{|c|c|c|c|}
\hline Appearance & $\begin{array}{r}\text { Unit } \\
\text { Measuring }\end{array}$ & $\begin{array}{r}\text { Specification } \\
\text { ASTM E291 } \\
{[53]}\end{array}$ & Results \\
\hline Copper as $\mathrm{Cu}^{+2}$ & Ppm & $\leq 4.0$ & 0.1 \\
\hline $\begin{array}{c}\text { Iron oxides } \\
\left(\mathrm{Fe}_{2} \mathrm{O}_{3}\right) \text {, max. }\end{array}$ & Percent & 0.01 & 0.005 \\
\hline $\begin{array}{c}\text { Manganese as } \\
\mathrm{Mn}\end{array}$ & Ppm & $\leq 4.0$ & 0.02 \\
\hline $\mathrm{Ni}^{+2}$ & Ppm & $\leq 5.0$ & 2.42 \\
\hline Silicate as $\mathrm{SiO}_{2}$ & Ppm & $\leq 20$ & 14 \\
\hline $\begin{array}{c}\text { Sodium } \\
\text { carbonate } \\
\left(\mathrm{Na}_{2} \mathrm{CO}_{3}\right), \text { max. }\end{array}$ & Percent & 0.40 & 0.36 \\
\hline $\begin{array}{c}\text { Sodium } \\
\text { chloride }(\mathrm{NaCl}), \\
\max .\end{array}$ & Percent & 0.15 & 0.07 \\
\hline $\begin{array}{c}\text { Sodium } \\
\text { hydroxide } \\
(\mathrm{NaOH}), \mathrm{min} .\end{array}$ & Percent & $\geq 97.5$ & 98.14 \\
\hline $\begin{array}{l}\text { Sulphate as } \\
\mathrm{Na}_{2} \mathrm{SO}_{4}\end{array}$ & Ppm & $\leq 200$ & 70 \\
\hline Water Insoluble & Ppm & $\leq 200$ & 60 \\
\hline
\end{tabular}

* According to manufacturer

\subsubsection{Sodium Silicate}

$\mathrm{Na}_{2} \mathrm{SiO}_{3}$ concentration is relying upon the proportion of $\mathrm{Na}_{2} \mathrm{O}$ to $\mathrm{SiO}_{2}$ and $\mathrm{H}_{2} \mathrm{O}$. This sort of $\mathrm{Na} 2 \mathrm{SiO} 3$ which was utilized in the current examination was made in the UAE. The qualities of the sodium silicate used shows in table (5).

\subsubsection{Coarse Aggregate}

Coarse aggregate (Al-Nebai region) natural gravel was used and examine the gradation, specific gravity, sulfate content, absorption. The outcomes show that it adapts to Iraqi standard IQS 45/1984 [16]. Examining, characteristics of coarse aggregate (chemical and physical) are shown in Tables, (6) and (7) respectively.

Table 5. Sodium Silicate's Properties *

\begin{tabular}{cc}
\hline Description & Value \\
The ratio of $\mathrm{SiO} 2$ to $\mathrm{Na} 2 \mathrm{O}$ & $2.4 \pm 0.05$ \\
$\mathrm{H} 2 \mathrm{O} \% \mathrm{wt}$ & 55.1 \\
$\mathrm{Na} 2 \mathrm{O} \% \mathrm{wt}$ & $13.10-13.70$ \\
$\mathrm{SiO} 2 \% \mathrm{wt}$ & $32-33$ \\
Density - $20^{\circ}$ Baumé & $51 \pm 0.5$ \\
Specific Gravity & $1.534-1.551$ \\
Viscosity (CPS) $20^{\circ} \mathrm{C}$ & $600-1200$ \\
Appearance & Vaporous \\
Description & Value
\end{tabular}

* According to Manufacturer.

Table 6. Natural Coarse Aggregate Examining*

\begin{tabular}{lcc}
\hline Sieve Size $(\mathrm{mm})$ & Passing \% & $\begin{array}{c}\text { IQS No.45- } \\
1984\end{array}$ \\
14 & 100 & $90-100$ \\
10 & 99 & $85-100$ \\
5 & 8 & $1-10$ \\
2.36 & 3 & $0-5$ \\
\hline * Gradation studies were carried out at the material \\
laboratory Mustansiriyah \\
Engineering.
\end{tabular}


Table7. Natural Coarse Aggregate Characteristics *

\begin{tabular}{ccc}
\hline Characteristics & Test Result & $\begin{array}{c}\text { IQS No.45- } \\
1984\end{array}$ \\
Absorption\% & 0.62 & --- \\
Gravity specifics & 2.6 & ---- \\
Sulfate content\% & 0.09 & $\begin{array}{c}0.1 \text { percent } \\
\text { maximum }\end{array}$ \\
\hline
\end{tabular}

* Tests were conducted in the University of Baghdad's directorate of construction science

\subsubsection{Fine Aggregate}

Fine aggregate (Al-Ekadir region) with maximum size $(4.75 \mathrm{~mm})$ was used as part of this work, so it is necessary to clean it before use. Tables (8) and (9) show the grade, physical and chemical characteristics of fine aggregates conforming to Iraqi standard specifications IQS (No. 45/1984) [15].

Table 8. Grading of Natural Fine Aggregate*

\begin{tabular}{|c|c|c|}
\hline $\begin{array}{lll}\text { Size } & \text { of } & \text { Sieve } \\
(\mathrm{mm}) & & \end{array}$ & $\begin{array}{l}\text { Cumulative } \\
\text { Percentage Passing }\end{array}$ & $\begin{array}{l}\text { IQS } 45-1984 \text {, } \\
\text { zone } 2\end{array}$ \\
\hline 10.0 & 100 & 100 \\
\hline 4.75 & 92.23 & $90-100$ \\
\hline 2.36 & 79.41 & $75-100$ \\
\hline 1.18 & 66.71 & 55- 90 \\
\hline 0.6 & 44.02 & $35-59$ \\
\hline 0.3 & 15.35 & $8-30$ \\
\hline 0.15 & 0.08 & $0-10$ \\
\hline
\end{tabular}

* The substance laboratory, the College of Engineering, the University of Mustansiriyah, carried out graduation examinations.

Table 9. Natural Fine Aggregate characteristic *

\begin{tabular}{lll}
\hline Characteristics & Result of Test & IQS 45-1984 \\
Absorption (\%) & 0.71 & ---- \\
Fineness modulus & 3.022 & ---- \\
Gravity specifics & 2.7 & ---- \\
Sulfate content\% & 0.36 & maximum 0.5 \\
& & $\%$ \\
\hline * The test was done in the University of Baghdad \\
Construction Study Directorate
\end{tabular}

\subsubsection{Hrwra}

To improve the workability of geopolymer concrete, the high range water reducer based upon the modified condensate of the sulfonated naphthalene formaldehyde has been used. The name of the product KUT PLAST SP400 has been provided from a local supplier. KUT PLAST SP 400 complied with the specification of the ASTM C494 type F. Table(10)illustrates the basic characteristics of the KUT PLAST SP 400[17].

Table 10. Superplasticizer characteristics (KUT PLAST SP 400)*

\begin{tabular}{|c|c|}
\hline Properties & Descriptions \\
\hline Specific gravity & $1.220-1.240$ at $20^{\circ} \mathrm{C}$ \\
\hline Colour & Light Brown \\
\hline Chloride content & Nil \\
\hline Air entrainment & $<1.0 \%$ \\
\hline Calcium Chloride content & Nil \\
\hline \multicolumn{2}{|l|}{ * According to Manufacturer. } \\
\hline \multicolumn{2}{|l|}{ 3.1.7. Additional Water } \\
\hline \multicolumn{2}{|c|}{$\begin{array}{l}\text { Additional water is the tap water for the concrete } \\
\text { mix design. }\end{array}$} \\
\hline
\end{tabular}

Two types of pigment were used in this research (yellow iron oxide hydroxide, and cobalt blue) of Chinese origin (granular size $<45$ microns) and used with different percent $(0,2,4,6) \%$ wt. of metakaolin.

\subsection{Colored Geopolymer Concrete Mixes}

Table 11(a) and 11(b) show the colored geopolymer concrete mixes. 
Table 11(a). Colored Geopolymer Concrete Mixes*

\begin{tabular}{cccc}
\hline Mix. & $\begin{array}{c}\text { MK, } \\
\mathrm{kg} / \mathrm{m} 3\end{array}$ & $\begin{array}{c}\text { The alkaline } \\
\text { solution, by } \\
\text { MK weight }\end{array}$ & $\begin{array}{c}\text { additional Water, } \\
\text { by MK weight }\end{array}$ \\
Mo & 400 & 0.65 & 0.12 \\
MY2 & 392 & 0.65 & 0.12 \\
MY4 & 384 & 0.65 & 0.12 \\
MY6 & 376 & 0.65 & 0.12 \\
MC2 & 392 & 0.65 & 0.12 \\
MC4 & 384 & 0.65 & 0.12 \\
MC6 & 376 & 0.65 & 0.12 \\
\hline
\end{tabular}

*Where Mo: Geopolymer concrete without pigments, MY: Geopolymer concrete with Yellow iron oxide hydroxide, and MC: with Blue cobalt

Table 11(b). Colored Geopolymer Concrete Mixes

\begin{tabular}{lllll}
\hline $\begin{array}{l}\text { Coarse } \\
\text { Aggregate } \\
\mathrm{kg} / \mathrm{m}^{3}\end{array}$ & $\begin{array}{l}\text { Fine } \\
\text { Aggregate } \\
\mathrm{kg} / \mathrm{m}^{3}\end{array}$ & $\begin{array}{l}\text { Pigment } \\
\mathrm{Kg} / \mathrm{m}^{3}\end{array}$ & $\begin{array}{l}\mathrm{HRW} \\
\mathrm{Ry}\end{array}$ & $\begin{array}{c}\mathrm{Na}_{2} \mathrm{SiO}_{3} \\
\text { ( }\end{array}$ \\
1200 & 650 & 0 & 3.5 & $\mathrm{NaOH}$ \\
1200 & 650 & 8 & 3.5 & $1: 2.5$ \\
1200 & 650 & 16 & 3.5 & $1: 2.5$ \\
1200 & 650 & 24 & 3.5 & $1: 2.5$ \\
1200 & 650 & 8 & 3.5 & $1: 2.5$ \\
1200 & 650 & 16 & 3.5 & $1: 2.5$ \\
1200 & 650 & 24 & 3.5 & $1: 2.5$ \\
\hline
\end{tabular}

\subsection{Preparation Alkaline Solution for Geopolymer}

\subsubsection{Preparing $\mathrm{NaOH}$ Solution}

The alkali solution of Geopolymer concrete has been constituted of two Ingredients (Na2SiO3 and $\mathrm{NaOH}$ ). The $\mathrm{NaOH}$ flakes with a high $98 \%$ purity can be made into a solution by dissolving them in distilled water. The mass of $\mathrm{NaOH}$ in the final solution varies depending on the $\mathrm{NaOH}$ solution's concentration. For eg, a 10 molar solution of $\mathrm{NaOH}$ contains $10 \times 40=400 \mathrm{~g}$ of
$\mathrm{NaOH}$ solids per liter, where 40 denotes the molecular weight of $\mathrm{NaOH}, \mathrm{O}=16, \mathrm{Na}=23$, and $\mathrm{H}=1$. The $\mathrm{NaOH}$ solid mass in this work has been evaluated as $262 \mathrm{~g}$ for each kilogram of the sodium hydroxide solution with an $8 \mathrm{M}$ concentration. Similarly, $\mathrm{NaOH}$ solid mass for each kilogram of solution for other concentration values has been measured as 10M: $314 \mathrm{~g}, 12 \mathrm{M}$ : 361g, 14M: 404g, and 16M: 444g, based on the ASTM E291-09[14] and (Hardjito and Ranga) [1]

Table 12. Slump test results for geopolymer concrete mixtures

\begin{tabular}{cc}
\hline Mix. & Slump $(\mathrm{mm})$ \\
Mo & 40 \\
MY2 & 39 \\
MY4 & 37 \\
MY6 & 32 \\
MC2 & 37 \\
MC4 & 35 \\
MC6 & 34 \\
\hline
\end{tabular}

\subsubsection{Preparation of the Alkaline Liquid}

Sodium silicate solution is available commercially in different degrees and has a $\mathrm{SiO}_{2}$ to $\mathrm{Na}_{2} \mathrm{O}$ relationship of 2.4 in the sodium silicate solution used in this analysis. The weight of components is proportionally water $=55.10 \%$, $\mathrm{SiO}_{2}=32.16 \%$ and $\mathrm{Na}_{2} \mathrm{O}=13.40 \%$. After preparing $\mathrm{NaOH}$ as a solution, the $\mathrm{Na} 2 \mathrm{SiO} 3$ solution will be added. The mixture of a solution of $(\mathrm{NaOH})$ and a solution of $\mathrm{Na}_{2} \mathrm{SiO}_{3}$ is alkaline fluid. The alkaline fluid should be prepared at least 24 hours before use, by combining solutions [1].

\subsection{Mixing Procedure for Colored Geopolymer Concrete}

First, in dry form, the coarse and fine aggregate has been mixed for 2-3 min using a 200-litter mixer. The pigments have been added into the dry mixture then metakaolin, prepared alkali liquid, superplasticizer, and additional water. for 
4min-5min final mixtures were carried out to reaching the homogeneity of the mixture [18][19].

\subsection{Curing}

This treatment procedure means positioning the specimen outside of the laboratory under direct sunlight for 28 days after demolding. Models have been poured over temperatures of $32^{\circ}$ to $36^{\circ}$, which are dependent on the previous studies [6] and which are positioned under ambient temperature.

\subsection{Fresh Properties( slump test)}

This test of colored geopolymer concrete was tested as a conventional concrete test. A slump test was conducted immediately after mixing. ASTM C143 [20].Table (12) shows the results of the slump test.

the test values for colored geopolymer concrete were less than the values of geopolymer concrete without pigments as a result of the effect of using (pigment) that have particles size are finer than MK, act as filler.

\subsection{Hardened Properties}

\subsubsection{Test of compressive strength}

According to (BS.1881: Part 116: 1989) [21], this test was carried out in three cubes with dimensions of $100 \times 100 \times 100 \mathrm{~mm}$ for each colored geopolymer mixture, tested with a 2000 KN hydraulic press. This test was performed after processing the samples for 28 days. Table 13 summarize the outcomes of the compressive strengths of the colored geopolymer concrete mixes.
Table 13. Compressive strengths of all colored geopolymer concrete mixes

\begin{tabular}{cc}
\hline Mix. & Compressive Strength(MPa) \\
Mo & 35.02 \\
MY2 & 37.22 \\
MY4 & 36.87 \\
MY6 & 35.93 \\
MC2 & 35.42 \\
MC4 & 35.21 \\
MC6 & 34.85 \\
\hline
\end{tabular}

The table includes the results of cubes for each color with different percentages of color addition. The $(2 \%)$ of color addition shows a higher value in the compressive strength for yellow and blue colored geopolymer concrete. However, with increasing this percentage of color addition, inverse behavior will appear on the results of compressive strength, the result shows a gradual decrease in the compressive strength.

Since the used pigment particles are finer than M.K particles, this means that the pigments tend to attract water molecules before they interact with M.K, thus reducing the water interacting with M.K, and thus tend to the strength of compressive improves. In general, increasing the amount of water tends to reduce the bond between bonding materials particles[22]. Pigments serve as a filler, reducing the porosity of hardened colored geopolymer concrete, resulting in an improvement in compressive strength, but, increasing the amount of pigment above of saturation point(Adding more pigment would only cover other pigment particles and is wasted) will reduce compressive strength due to the agglomeration of the pigment particles, this lead to the formation of segregation zone for colored geopolymer concrete [23]. 


\subsubsection{Flexural strength}

Flexural strength is a material property described as the tension in a material just before it is tested in a bending test, Also known as bend strength, or rupture modulus [24]. The $(100 \times 100 \times 500) \mathrm{mm}$ three prisms for every one of the mixes of colored geopolymer concrete with Two-Point Loading tested the value of the flexural strength, based on the ASTM C 78[25]. The modulus of rupture can be computed from a simple formula of the beam bending:

$$
R=p l / b d^{2}
$$

$\mathrm{R}$ represents the rupture Modulus, $(\mathrm{MPa})$

1 represents the length of the Span, (mm)

$\mathrm{p}$ represents the Maximum applied load which has been indicated with a machine of testing, $(\mathrm{N})$

$\mathrm{d}=$ specimen's Depth $(\mathrm{mm})$

$\mathrm{b}=$ specimen's Width $(\mathrm{mm})$

The flexural strength outcomes are in Table 14.

Table 14. Flexural strength of geopolymer concrete mixes

\begin{tabular}{cc}
\hline Mix. & Flexural Strength(MPa) \\
Mo & 4.81 \\
MY2 & 4.89 \\
MY4 & 4.86 \\
MY6 & 4.78 \\
MC2 & 4.87 \\
MC4 & 4.82 \\
MC6 & 4.63 \\
\hline
\end{tabular}

The addition of color shows an increase in Flexural strength with a behavior similar to the compressive strength.

\subsubsection{Rebound Number}

This test was carried out according to ASTMC 805 [26] for each mixture of colored geopolymer concrete. The concrete surface should be cleaned and smothered before applying the hummer. At least 10 readings compared and each reading should not differ by more than 7 units. The average of remaining readings is determined to evaluate strength. If more than 2 readings are different from the average by 7 units, then the whole set of readings will be taken again [27]. The Rebound Number outcomes are in Table 15.

Table 15. Rebound Number of geopolymer concrete

\begin{tabular}{cc}
\multicolumn{2}{c}{ mixes } \\
Mix. \\
Mo & 35.7 \\
MY2 & 35.92 \\
MY4 & 35.89 \\
MY6 & 35.81 \\
MC2 & 35.77 \\
MC4 & 35.76 \\
MC6 & 35.72 \\
\hline
\end{tabular}

The addition of pigment to geopolymer concrete increases the values of the Rebound number, this increase is due to the filling of the pores, especially the pores in the sample surface and close to the surface.

\subsubsection{Ultrasonic Pulse velocity test}

This test has been carried out with each mixture based on the ASTM C-597 of colored geopolymer concrete [28]. The pulse Velocity $(\mathrm{V}=\mathrm{L} / \mathrm{T})$ can be calculated with measured travel time $\mathrm{T}$ (sec) and distance between two props $\mathrm{L}$ (m). The transducers can be arranged, as can be seen from Fig. 1 in 3 potential configuration types. Those are (a) direct (b) indirect, (c) semidirect transmission.

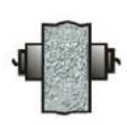

a)

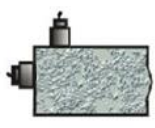

b)

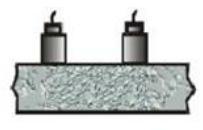

c)
Figure 1. Methods of the transmission of pulse velocity ultrasonic 
In this work, a direct test approach was used to the samples of geopolymer concrete. The results are shown in Table 16.

Table 16. UPV test results of geopolymer concrete mix

\begin{tabular}{cc}
\hline Mix. & Velocity $(\mathrm{m} / \mathrm{s})$ \\
Mo & 3616 \\
MY2 & 3806 \\
MY4 & 3798 \\
MY6 & 3630 \\
MC2 & 3613 \\
MC4 & 3682 \\
MC6 & 3495 \\
\hline
\end{tabular}

It can be seen that the velocity of the pulse increases, which means less pore content and high density because the pigments play a big role in filling the pores and thus increase the pulse velocity.

\subsubsection{Relation between destructive and nondestructive}

From experimental findings of the compression test and non-destructive test, the equation can be made with two variables (velocity of the wave and rebound number R.N), non-destructive test (N.D.T) is used to appreciation compressive strength. In this study computer software program curve, expert pro has been used.

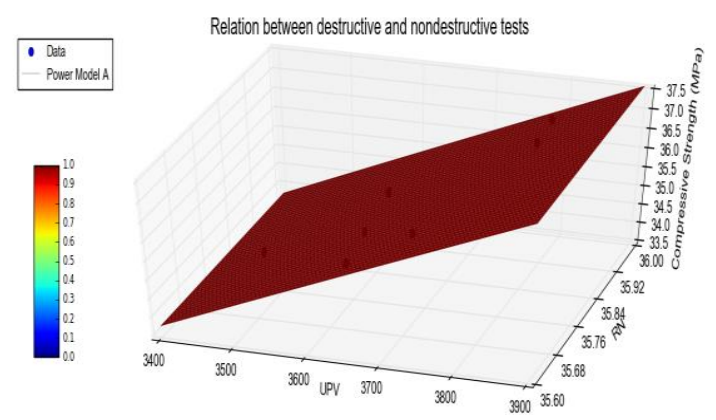

Figure 2.The connection between NDT (UPV\&RN) and compressive strength test
Compressive Strength $(\mathrm{MPa})=a *\left(U P V^{\wedge} b+\right.$ $R N^{\wedge} \mathrm{C}$ )

Where: UPV represents ultrasonic pulse velocity, $(\mathrm{m} / \mathrm{s})$

$\mathrm{RN}$ represents rebound number

$\mathrm{a}=0.055$

$\mathrm{b}=0.7888$

$c=-15.6556$

Correlation Coefficient: 0.91

\subsubsection{Absorption of water}

The absorption of water is generally determined when the sample is dried up to a constant mass and immersing to water and the rise in mass is measured as a percentage of a dry mass according to (ASTM C 642) [29]. The specimen was a cube $(100 \times 100 \times 100) \mathrm{mm}$; Absorption of water as fallow is measured:

percentage of absorption of water $=[(W 2-$ $W 1) / W 1] \times 100 \%$

In which:

W1: Mass of Oven-Dry, at a temperature of 100 $-110^{\circ} \mathrm{C}$ for not little than $24 \mathrm{~h}$.

W2: Saturated Mass after immersion the specimen in water at around $21^{\circ} \mathrm{C}$ for not little than $24 \mathrm{~h}$. The outcomes are shown in table (17).

Table 17. Water absorption results of geopolymer concrete mix

\begin{tabular}{cc}
\hline Mix. & Water absorption \\
Mo & 4.80 \\
MY2 & 4.72 \\
MY4 & 4.69 \\
MY6 & 4.65 \\
MC2 & 4.77 \\
MC4 & 4.76 \\
MC6 & 4.71 \\
\hline
\end{tabular}


Due to the role of the pigments that were used in this study, which act as fillers inside the colored geopolymer concrete mixtures, which will reduce the porosity and thus reduce the water absorption of the hardened colored geopolymer concrete.

\section{Conclusions}

This work had studied some of the mechanical and physical characteristics of colored geopolymer concrete with different types of pigment (Yellow iron oxide hydroxide and Blue cobalt). The values of the slump test had been decreased with increase pigment percentage for all pigment types. A higher value of compressive strength for all pigments can be achieved with the addition (2\%) of pigment. The results indicate that the higher percentage of increase in strength of compressive for (2\%) of yellow and blue are (6.28 and 1.14) respectively, and with increasing addition percentage of pigment then the compressive strength will decrease. The best value of flexural strength for all pigments can be achieved with the addition ( $2 \%$ ) of pigment. The results indicate that the higher percentage of increase for (2\%) of yellow, blue are (1.66 and 1.25) respectively, and with increasing addition percentage of pigment then the flexural strength will decrease. As for the rebound number, it had the highest value with the addition (2\%) pigment, as it increased in percentages (0.61 and 0.196$)$ for yellow and blue, respectively. The UPV increased and the greatest value was when adding a $(2 \%)$ pigment in percentages $(5.25 \%$ and $1.8 \%)$ for yellow and blue respectively.

The absorption of water decrease with the addition of pigment, where the lowest value is at the percentage of pigment $(6 \%)$ of yellow and blue is $(3 \%$ and $1.8 \%)$ respectively.

\section{Acknowledgements}

Authors are grateful to all support given by the College of Engineering, the University of Mustansiriyah for academically support.

\section{Conflict of Interest}

The author confirms that the publication of this article causes no conflicts of interest

\section{References}

1. Sumajouw, D. Hardjito, S. E. Wallah, and B. V Rangan.( 2005). "Fly ash-based geopolymer concrete: An application for structural members," World Congr. GEOPOLYMER 2005 Geopolymer; Green Chem. Sustain. Dev. Solut.,.

2. B. A.-K.-D. de E.( 2007).Civil and undefined, "An Experimental Study on Colored Concrete using Pigments from Raw Local Materials."

3. Marín-López et al., (2009). "Synthesis and characterization of a concrete based on metakaolin geopolymer," Inorg. Mater., vol. 45, no. 12, pp. 1429-1432.

4. Rovnaník,P. ( 2010) ."Effect of curing temperature on the development of hard structure of metakaolin-based geopolymer," Constr. Build. Mater., vol. 24, no. 7, pp. 1176-1183.

5. Cheng, M. L. Lee, M. S. Ko, T. H. Ueng, and S. F. Yang. (2012). "Applied Clay Science The heavy metal adsorption characteristics on metakaolin-based geopolymer," vol. 56, pp. 90-96.

6. Al-Shether, T. Al-Attar, and Z. A. Hassan. (2016). "Effect of Curing System on Metakaolin Based Geopolymer Concrete," J. Univ. Babylon - Eng. Sci., vol. 24, no. 3, pp. 569-576.

7. Sahar Jabbar M. AL-Serai. (2019). "Structural Behavior of Fiber Reinforced Geopolymer Concrete Wall Panels," M.Sc. Civ. Eng. / Al-Mustansiriyah Univ. 
8. Bruce, G. R.-P. (1992). "The influence of pigments on mix designs for block paving units."

9. Lee, J. Y. Lee, and M. Y. Yu. (2003). "Influence of iron oxide pigments on the properties of concrete interlocking blocks," Cem. Concr. Res., vol. 33, no. 11, pp. 1889-1896, Nov.10.1016/S00088846(03)00209-6.

10. Fujii, A. Fujiki, H. Tanaka, and T. Ayano.( 2005). "Effect of dosage of pigment on the surface color of concrete," Zair. Soc. Mater. Sci. Japan, vol. 54, no. 8, pp. 810 815.

11. Hospodarova, J. Junak, and N. Stevulova.( 2015). "Color pigments in concrete and their properties," Pollack Period., vol. 10, no. 3, pp. 143-151, Oct.

12. Feng, R. Zhang, L. Gong, Y. Li, W. Cao, and X. Cheng.( 2015). "Development of porous fly ash-based geopolymer with low thermal conductivity," Mater. Des., vol. 65, no. November 2017, pp. 529-533.

13. Salvador.( 1995) "Pozzolanic properties of flash-calcined kaolinite: A comparative study with soak-calcined products," Cem. Concr. Res., vol. 25, no. 1, pp. 102-112, Jan.

14. A. S. for $T$. and materials Materials, "Standard Specification for Coal Fly Ash and Raw or Calcined Natural Pozzolan for Use in Concrete," 2002.

15. ASTM E291. (2009). "Standard Test Methods for Chemical Analysis of Caustic Soda and Caustic Potash (Sodium Hydroxide and Potassium Hydroxide) ", American Society for Testing and Materials,

16. IOS No.45. (1984). Iraqi Specification, "Aggregate from Natural Sources for Concrete and Construction", Central Agency for Standardization and Quality Control, Baghdad.
17. ASTM C494. (2004). "Standard Specification for Chemical Admixtures for Concrete", Annual Book of American Society for Testing and Material Standards,

18. Lloyd and B. V. Rangan. (2010). "Geopolymer concrete with fly ash," 2nd Int. Conf. Sustain. Constr. Mater. Technol., vol. 7, pp. 1493-1504.

19. Abdulrehman. (2012). "Studying Mechanical and Physical Properties of Colored Concrete,".

20. ASTM C143 / C143M - 10a. (2010). "Standard Test Method for Slump of Hydraulic-Cement Concrete" American National Standard, , 3pp. .

21. BS 1881-114.(1983). Testing concreteMethods for determination of density. British Standard."

22. Neville, A.M. (2005). Properties of concrete, fourth and final edition, Lomgman,. P. 78."

23. Abdulrehmman. (2012) "Studying Mechanical and Physical Properties of Colored Concrete".

24. ASHBY and D. CEBON.( 1993)."Materials selection in mechanical design," Le J. Phys. IV, vol. 03, no. C7, pp. C7-1-C7-9, Nov.

25. ASTM C78. (2005). "Standard Test Method for Flexural Strength of Concrete", American Society for Testing and Materials, .

26. ASTC M805 .(1993)Test for Rebound Number of Hardened Concrete,American Society for Testing and Materials.

27. IS 13311-2. (1992). Method of nondestructive testing of concrete methods of test, part 2: rebound hammer. New Delhi: Bureau of Indian Standards. - Bing.”.

28. ASTM C597. (2003). Standard Test Method for Pulse Velocity through Concrete", 
American Society for Testing and Materials, .

29. ASTM C642. (2004). "Standard Test Method for Density, Absorption, and Voids in Hardened Concrete", American Society for Testing and Materials. 